\title{
Artistic interpretation of the mythonyms of Angel and Devil in the works of A.Navoi
}

\author{
Rajabova Marifat Bakaevna \\ Associate Professor of \\ Uzbek Literature department \\ Bukhara State University
}

\begin{abstract}
The work of Hazrat Alisher Navoi was formed on the basis of a spiritual treasure that has passed a rich and long historical path of development. The work of the great poet is connected with the oral tradition of the people on the one hand, and with the Qur'an and Hadith, which are the main sources of Islam, on the other hand. Stylistic folklorisms emerged as a result of the effective influence of folklore genres, motives and images in the works of A. Navoi. In the article A. The originality of the use of angelic and satanic mythonyms used in Navoi's works and the motives put forward by them are analyzed.
\end{abstract}

Key words: folklore, myth, written literature, angel, devil, fairy, spirit.

\section{I.Introduction}

It is well known that in the history of literature, the place of each writer, poet is determined by his attitude to the literary traditions of his own and the extent to which he was able to develop it in accordance with the requirements of his time. When it comes to the sources of Alisher Navoi's works, it should not be overlooked that he was thoroughly acquainted with the unique Arabic, Persian and Turkish literary and spiritual heritage. He learned from their best traditions, was influenced, and developed them in his literary experience. While religious, divine and mystical sources served to clarify the religious views of the great poet, folklore materials served to illuminate the spiritual world of the lyrical hero, the issues of love and romance. This served to ensure that the works of the great poet were, on the one hand, popular and, on the other hand, in harmony with the hearts of the people.

\section{II.Literature review}

It should be noted that special place in the lyrical and historical works of A.Navoi belongs to the stylistic folklore, formed under the influence of motives and images typical of the Uzbek folklore. In particular, the ideas and motives put forward through religious-mythological images are interpreted in accordance with the reflection of the period in which the poet lived and the nature of the lyrical hero. Such images include angels (malachite), heaven, hell, fairies, dragons, snakes, and giants.

Alisher Navoi not only gives the lines of his time through these images, but also emphasizes the religious beliefs and rituals of the people. We want to base our opinion on the images of angels and devils used in the works of the poet.

\section{III.Analysis}

According to religious sources, God created living things in three parts. These are the worlds of angels, human beings and animals. He was created from light and imagined as a spirit. In Nasiruddin Rabguzi's Qissasi Rabguzi, it is written: The originals stand together, but there are three differences. One is standing, the angels are standing in the light, the fairies are standing. Secondly, angels are called malachites, fairies are called demons. Thirdly, the place of angels will be in heaven, and the fairies will be on earth" $[10,13]$. Thus, the creation of angels from light and the qualities of purity, innocence, beauty and purity have led to the widespread use of this image in the works of our classical poets.

According to popular belief, angels represent the spirit world. Such views were formed in the Turkic peoples before the advent of Islam. The idea of angels flying around a fire and dancing is related to the religious beliefs of the people. Of course, such views are the product of Zoroastrianism.

Gar o'sam ul malaksiymo pariy hajrinda, aylang'ay

Pariy birla malak parvonadek sham'i mazorimg'a [7, 380]. in my tomb.

If I die in the pilgrimage of that beautiful malachite, the malachite and the angels will revolve around the candle

According to the beliefs of the Turkish people, after the death of a person, his soul flies away as a soul. It is therefore customary among the people to light a lamp for forty days for the souls of the dead, which has survived to this day. In the above verse, too, the poet is based on this view of the angel and artistically reflects the mental state of the lyrical protagonist. The following verse also describes an angel as a propeller on a candle.

Yopsa yuz har necha ko'nglum qushidin tong yo'qqim,

Malak ul sha'mi jahon tobiga parvona emish[7, 190].

That is, if the lover hides the face of the bird of my heart, do not be surprised that the angel is a propeller to the 
light that illuminates the world.

"Bird of the heart" is a metaphor for the soul of a lover. The images used in the works of Alisher Navoi, such as "bird of the soul", "bird of the heart", "nightingale of the soul" are also based on animistic ideas [2,146].

So, even in the above verse, the fact that the angel is a propeller around the world (illuminating the world) is, of course, related to the first ideas about the world of spirits.

G'amingdin, ey pariy, devona bo'lmas,

Kishikim hush topchoq, yona bo'lmas.

Jamoling sha'mig'a ko'nglum qushidek

Maloyik xayli ham parvona bo'lmas[6,178].

O pari, once a man has accepted your grief, he will no longer be mad. The swarm of angels will not fly to the light of your beauty like a bird of my heart.

In the verses quoted we can see that the mythological views peculiar to angels and fairies prevailed. The poet skillfully used the ideas about the insanity of a man who met a fairy in public to express his ideas in an exaggerated way. The fact that the bird of the soul (the heart, the spirit of the lover) is a propeller to the beauty of the mistress is even more important than the propeller characteristic of angels.

Ul pariy hajrinda men devona cheksam o'tluq oh,

Ey malak, gar bo'lmasang voqif, qanoting churkanur[6, 130].

According to animistic views, angels (malachite) were imagined to be winged, they were flying. The above byte also indicates this. That is, the lyrical protagonist sighs grassy sigh in love. As a result, the wing of the angel, who is unaware of the lover's condition, burns. In this verse, too, the idea of angels as representatives of the spirit world is striking.

Aningdek soldi ishqing shu'la jonim ichkarim, shaksiz

Maloyik barcha kungay, ko'kka tushsa bir sharar mendin[6, 341].

Your love has set my soul on fire so much that if a spark falls from it into the sky, the angels will surely burn.

The love of the lover ignites two worlds. Even angels made of light burn with the spark of love. The idea that "the place of angels will be in heaven" in the "Qissasi Rabguzi" also served the idea of this verse.

The view that angels have wings was the basis for creating the original image in the following byte.

G'am shomi gar o'tumg'a bo'lur sham ashkrez,

Parvonalar qanoti yeli aylar ani tez[5, 156]

Because of the lover's love, the candle became a tear-jerk. The hand (wind) of the wing of the angels, which was propelling around the candle, caused it to accelerate. When the poet said butterflies in the byte, he meant angels. It should be noted that the literature reflects the essence of the universe and man artistically by describing the struggle between the world of good and evil. Therefore, any positive image, which is an artistic product of human thinking, came into the world in opposition to the emblem. Satan is one such image. A. In Navoi's lyrics, too, this image was created under the influence of mythological and religious views. In the Annotated Dictionary of the Uzbek Language: "Satan in Arabic is the devil; gin, genie. The head of an evil spirit or evil spirits who lead people astray from the path of religion, leading them to sin, crime, depravity; the devil "[9,608]. The image of Satan is present in the literature of all nations and is called by various names. Religious sources served as the basis for the formation of this image in fiction.

\section{IV.Discussion}

The basis of A.Navoi's works is a didactic idea. Because a society can be perfect and just if its members are morally well behaved. To do this, the poet always implies that the leaders of the state and religion must first have such morals. Because they are a mirror for the people. However, there are many examples in the lyrical heritage of A.Navoi that such leaders have been criticized. One such image is the image of sheikhs. Hypocritical sheikhs have also been criticized in the verses quoted below. They are equated with the devil in deception.

Ul shayxki minbar uza afsung'a berur tul.

Shaytondur o'zi, majlisining ahli suruk g'ul[7, 265].

It is known that in the creation of man, every rock on earth was taken from the soil. When God breathed into a man, He commanded him to worship the angels. One of them disobeyed the treasurer of Paradise, Azazil (Iblis, Satan) because he was created from fire, and Allah expelled him from Paradise. It is written in the Holy Book: "(Satan said) I do not worship what You have created from clay. I am better than he, You created me from fire, and You created him from clay.’(Surat al-A'raf: 12)

Hence, the satanic qualities of arrogance, hypocrisy and arrogance have been passed on to the sheikhs. In the verse, they are depicted as arrogant and deceiving the people. Those in the meeting of the satanic sheikh are also the ones who accept his spells and tricks, that is, the "ahli suruk g'ul" (a group of ghosts).

"In the dictionary of A. Navoi's works it is interpreted as "flower - giant, flower desert - desert giant" [8,755]. In our literature, studies on the origin of the flower myth have noted that "although the word originally meant 'mythological being specific to the female sex' in Arabic, it was assimilated into the Turkic languages in an asexual way" [3,21]. "Ghosts are female spirits who are hostile to man in Muslim mythology. Ghosts change their appearance, misleading passengers 
and killing and eating them. The notion of ghosts goes back to the pre-Islamic ancient views of the Arabs; they are particularly mentioned in the epic Taabbat Sharan (sixth century AD). The image of a ghost is common in folklore. The male of the ghost is called "qutrub" [1,57].

It is known that the devil, under the guise of "helper", "guide", "colleague", leads people astray. The poet equates the sheikhs with the devil in order to give them the same quality. So, A. Navoi brings the myths of the devil and the ghost to each other as like-minded, conversationalists to ensure the effectiveness of thought and idea.

Gar odame malak o'lsaki, qilmasun ta'rif,

Agar kishi desakim, yetmagay xijolat anga.

Yomonni demaki, izlol etar ekin shayton,

Degil: fasodda mundin yetar zalolat anga[7, 7].

The spirit of admonition prevails in the verses quoted. That is, even if a person is an angel, he should not exaggerate, so there will be no shame. Do not say evil, Satan is the one who leads astray to lead astray.

According to religious beliefs, the main task of the devil is to lead people astray, to lead them astray. The quote refers to Satan's expulsion from the world of angels because of his arrogance, and urges man to stay away from arrogance.

Both in religious sources and in the works of classical artists, arrogance is condemned as the most harmful vices in the human body. In A.Navoi's lyrical heritage, this flaw in the image of the devil is often criticized.

Ko'ng'il o'zlukni gar odam esang, inak shayton

(If you're a selfish person, you're a devil)

Kibr ila nayladi ko'r, oncha ibodat aylab

(He was blinded by pride and prayed a lot [5.45].)

Byte while criticizing one of the negative qualities of man, A.Navoi refers to the religious narration associated with the devil as a parable. In Surat al-Kahf, it is stated in the Qur'an that when Allah created Adam and commanded all the angels to worship him, only the devil was arrogant and did not worship him. Hazrat Navoi also refers to the myth of the devil to emphasize that it is arrogance that deprives man of humanity.

It should be noted that in A.Navoi's lyrics, there are many verses that promote the idea of glorifying women by likening them to angels. However, the poet does not ignore the fact that the devil's tricks did not bypass women either.

Ey Navoiy, vo'sma birla kesmadin topqan firib,

Gar malakdurkim, bo'lur shaytonsifatlar mahzali[4,575].

The byte quoted refers to women using the phrase "bo'sma bilan kesma"(cut with a kiss). The eyebrow, the cut, refers to "women's hair cut on both sides for decoration." According to the poet, if women have deceit and deception, even if they are beautiful, satanic people will be ridiculed.

\section{V.Conclusion}

The following conclusion can be drawn by analyzing the mythonyms of the angel (malachite) and the devil used in the lyrics of A. Navoi:

- Malachite is a synonym of the word angel and has two meanings in the poet's lyrics. That is applied to the world of angels and a very beautiful mistress.

- The image of the angel promotes the ideas of innocence, purity, love, while the image of the devil condemns arrogance, hypocrisy, writing, corruption, enmity, evil.

- An angel is a symbol of innocence. This is why it is often imagined as a winged, flying image. The same notion in the people has been skillfully used to depict the mental state of the lover, and to give a beautiful image of the lover.

- The analysis shows that in Navoi's lyrics the images of angels and fairies are used side by side. The basis for this is, firstly, that they are both representative of the spirit world, and secondly, that the basis of their emergence is the same. That is, an angel is made of light, a fairy is made of wood.

- In the image of the angel lyrical experiences, romantic relations are expressed, and through the myth of the devil the social, religious-philosophical and ideological ideas are artistically reflected.

- It is obvious that the basis of Alisher Navoi's views on the myth of the angel and the devil is based on the Qur'an and religious mythology.

- Satan, as a "patron", encourages people to commit inhumane ways, sins and blasphemies under the guise of innocence and innocence. Therefore, in the poet's lyrics, the priority of the motive of protecting people from it is obvious.

In short, the originality in the use of traditional themes and images, poetic emblems, artistic means of depiction gave color to the work of the great poet. This can also be observed in the process of artistic interpretation of the myth of the angel and the devil, which is often seen in the poems of the poet alone.

\section{References:}

1. Valyanskaya O. Woman in myths and legends. - Toshkent, 1992.

2. Jo'raev M., M. Narzikulova. Myth, folklore and literature. - T .: A. Publishing House of the National Library of Uzbekistan named after Navoi. 2006. 
3. Musaeva Feruza. Expression of the concept of gender in the Uzbek language. Author's abstract of the dissertation of the doctor of philosophy (phd) on philological sciences.2019.

4. Navoi Alisher. A perfect collection of works. Volume XX. I skin. Badoe' ul-bidoya. - T .: Fan, 1987.

5. Navoi Alisher. A perfect collection of works. Volume XX. Volume IV. Navodir ush-shabab. - T .: Fan, 1989.

6. Navoi Alisher. A perfect collection of works. Volume XX. V skin. Badoe' ul-vasat. - T .: Fan, 1990.

7. Navoi Alisher. A perfect collection of works. Volume XX. Volume VI. Favoyid ul-kibar. - T .: Fan, 1990.

8. Dictionary of Navoi works. - T .: G'. Gulom Publishing House of Literature and Art.1972.

9. Annotated dictionary of the Uzbek language. Volume VI. - T .: State Publishing House "National Encyclopedia of Uzbekistan". 2008.

10. Rabguzi Nosiruddin Burhonuddin. The story is Rabguzi. The first book. - T.$:$ Writer, 1990.

11.Z.Q.Amonova. G.A.Murodova. Mansur Hallaj and his ideas in Ahmad Yassavi's works. International Scientific Journal Theoretical \& Applied Science p-ISSN: 2308-4944 (print) e-ISSN: 2409-0085 (online) Year: 2020 Issue: 04 Volume: 84. Published: 30.04.2020 http://T-Science.org Pag.964-967 